\title{
Effects of virginiamycin and galbanum (Ferula gummosa boiss) on performance, carcass traits, immune system and blood parameters of broiler chickens
}

\author{
Efectos de la virginiamicina y el gálbano (Ferula gummosa boiss) sobre la producción, características de \\ la canal, sistema inmune y parámetros sanguíneos en pollos de engorde \\ Efeitos na adição na dieta do virginiamicina e do gálbano (Ferula gummosa boiss) no desempenho, \\ características da carcaça, sistema imunológico e fatores sanguíneos de frangos de corte
}

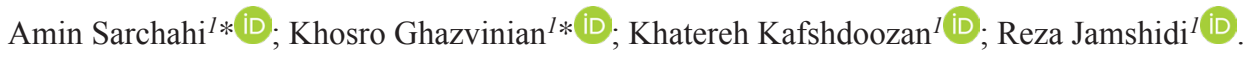

${ }^{1}$ Department of Animal Science, Faculty of Veterinary Medicine, Semnan University, Semnan, Iran.
\end{abstract}

To cite this article:

Sarchahi A, Ghazvinian K, Kafshdoozan K, Jamshidi R. Effects of virginiamycin and galbanum (Ferula gummosa boiss) on performance, carcass traits, immune system and blood parameters of broiler chickens. Rev Colomb Cienc Pecu 2022; 35(4): 191-204. DOI: https://doi.org/10.17533/udea.rccp.v35n3a03

\begin{abstract}
Background: Some medicinal plants can stimulate growth in poultry. Objective: To compare the effects of dietary addition of virginiamycin antibiotic and galbanum plant (Ferula gummosa) on the performance, carcass characteristics, immune system, and blood factors of broiler chickens. Methods: A total of 250 one-day-old male Ross 308 broiler chickens were randomly assigned to five treatments with five replicates (10 birds per replicate). The treatments were: control (basal diet), virginiamycin (basal diet plus $0.1 \mathrm{~g}$ virginiamycin $/ \mathrm{kg}$ of diet) or one of three levels of galbanum powder $(2.5,5$, and $10 \mathrm{~g}$ galbanum $/ \mathrm{kg}$ of diet). Results: Body weight gain, feed intake and feed conversion ratio improved in the groups containing galbanum compared to the other groups $(p<0.05)$. The percentage of liver, heart and abdominal fat decreased in the treatments containing 5 and 10 g galbanum compared to the control $(p<0.05)$. Spleen weight and antibody titers against Newcastle disease and SRBC were significantly increased in the treatment containing $10 \mathrm{~g}$ of galbanum compared to the other treatments $(p<0.05)$. The addition of galbanum powder resulted in a significant decrease in serum cholesterol, triacylglycerol, and LDL $(p<0.05)$. Additionally, galbanum increased serum total protein, albumin, globulin, and HDL $(p<0.05)$. Conclusion: Galbanum improves performance and the immune system of broiler chickens, and has similar growth promoting effects as virginiamycin.
\end{abstract}

\section{Received: March 10, 2021; Accepted: October 8, 2021}

*Corresponding author. Semnan - Opposite Sokan Park, Campus No. 1, Faculty of Veterinary Medicine, Semnan University, Postal Code: 19111-35131. E-mail: khghazvinian@semnan.ac.ir 
Keywords: Antibiotic; broiler; chicken; carcass; galbanum; growth performance; immune response; medicinal plants; virginiamycin.

\section{Resumen}

Antecedentes: Algunas plantas medicinales pueden estimular el crecimiento de las aves. Objetivo: Comparar los efectos de añadir virginiamicina y gálbano (Ferula gummosa) a la dieta sobre la producción, características de la canal, sistema inmune y parámetros sanguíneos de pollos de engorde. Métodos: Un total de 250 pollos machos de engorde Ross 308 con un día de vida se asignaron aleatoriamente a cinco tratamientos ( 5 réplicas y 10 aves por réplica). Los tratamientos fueron: control (dieta basal), virginiamicina $(0,1 \mathrm{~g}$ virginiamicina $/ \mathrm{kg}$ dieta) y tres niveles de gálbano en polvo $(2,5,5 \mathrm{y} 10 \mathrm{~g}$ galvano/kg dieta). Resultados: La ganancia de peso, el consumo de alimento y el índice de conversión mejoraron en los tratamientos que contenían gálbano comparados con los otros grupos $(p<0,05)$. los porcentajes de grasa hepática, cardíaca y abdominal se redujeron significativamente en los tratamientos que contenían $5 \mathrm{y} 10 \mathrm{~g} / \mathrm{kg}$ de gálbano comparados con el control $(p<0,05)$. El peso del bazo y la producción de anticuerpos contra las enfermedades de Newcastle y SRBC aumentaron significativamente en el tratamiento con $10 \mathrm{~g} / \mathrm{kg}$ de gálbano en comparación con los otros tratamientos $(p<0,05)$. La adición de gálbano resultó en una disminución significativa de los niveles de colesterol, triglicéridos y LDL $(p<0,05)$, mientras que los niveles séricos de proteína total, albúmina, globulina y HDL aumentaron significativamente $(p<0,05)$. Conclusión: Los resultados mostraron que el gálbano mejora la producción y refuerza el sistema inmune en pollos de engorde, y promueve el crecimiento de forma similar a la virginiamicina.

Palabras clave: antibiótico; canal; gálbano; hierbas medicinales; pollos; rendimiento de crecimiento; respuesta inmune; virginiamicina.

\section{Resumo}

Antecedentes: Algumas plantas medicinais podem estimular o crescimento dos pássaros. Objectivo: Comparar os efeitos da adição na dieta do antibiótico virginiamicina e do gálbano (Ferula gummosa) no desempenho, características de carcaça, sistema imunológico e fatores sanguíneos de frangos de corte. Métodos: Um total de 250 frangos de corte, machos Ross 308, de um dia de idade foram aleatoriamente divididos em 5 tratamentos e 5 repetições (10 aves por repetição). Os tratamentos foram: grupo controle (dieta base), grupo com adição de antibiótico virginiamicina $(0,1 \mathrm{~g}$ virginiamicina $/ \mathrm{kg}$ de dieta) e três outros grupos com diferentes níveis gálbano em pó (2,5,5 e $10 \mathrm{~g}$ galvano/kg de dieta). Resultados: O ganho de peso corporal, o consumo de ração e a taxa de conversão melhoraram nos grupos contendo 5 e 10 gramas de gálbano em comparação com os outros grupos $(p<0,05)$. As diferenças no percentual de gordura hepática, cardíaca e abdominal diminuíram significativamente nos tratamentos contendo 5 e $10 \mathrm{~g}$ de gálbano em comparação ao controle $(p<0,05)$. O peso do baço e os títulos de anticorpos gerados contra a doença de Newcastle e SRBC foram significativamente aumentados no tratamento contendo 10 gramas de gálbano em comparação com os outros tratamentos $(p<0,05)$. A adição de gálbano em pó resultou em diminuição significativa do colesterol sérico, triacilglicerol e LDL $(p<0,05)$ e, por outro lado, aumento significativo da proteína sérica total, albumina, globulina e HDL $(p<0,05)$. Conclusões: Os resultados mostraram que a erva medicinal gálbano melhora o desempenho e estimula o sistema imunológico em frangos de corte e pode ser considerada um factor de crescimento em frangos de corte em comparação com o antibiótico virginiamicina.

Palavras-chave: antibiótico; carcaça; desempenho de crescimento; frango de corte; gálbano; planta medicinal; resposta imune; virginiamicina. 


\section{Introduction}

Broiler meat is one of the largest sources of animal protein world wide. This industry is well developed in several areas, such as nutrition, genetics, and management (Chen et al., 2008), with increasing focus on community health and the environment.

Additives are used in poultry feeding to increase yield, trying to ensure that their desired effects are held while harmful environmental and health effects are avoided (Ahmadi et al., 2019). Several antibiotics have been used as growth promoters in poultry nutrition to improve performance by preventing growth of intestinal pathogens. Consumers are very concerned about the excessive use of antibiotics in poultry production due to increased bacterial resistance in humans (Abedi et al., 2008). Europe has banned the use of growth promoting antibiotics in farm animals, thus the poultry industry needs to find suitable alternatives (Poorghasemi et al., 2018).

Medicinal plants had been neglected in modern feeding of livestock and poultry due to the effectiveness of antimicrobial growth promoters. After the ban on antimicrobial growth promoters, several herbs have attracted the attention of researchers (Poorghasemi et al., 2014). Medicinal plants contain phenols, polyphenols, terpenoids, volatile oils, alkaloids, and antimicrobial compounds that can stimulate digestion, decrease lipid and cholesterol levels, stimulate the immune system, increase antibody production, and promote growth (Soltan et al., 2008). Many recent studies have focused on trying to find alternatives to growth-promoting antibiotics (Greathead, 2003). Aditionally, research has shown that various herbs and essential oils can lower cholesterol (AdaszyńskaSkwirzyńska and Szczerbińska,2019). Extracts from some plants, such as summer savory (Satureja hortensis L.), have also shown beneficial effects on performance, immune response, hematology, and microbiota of broilers (Movahhedkhah et al., 2019).
Ferula gummosa boiss, commonly known as galbanum, is a medicinal plant of family Apiaceae or Umbelliferae, which has 275 genera and 2,850 species (Klaverand Van Der Meer, 1993). Galbanum produces an oleo-gum resin that is mostly present in the root. This material contains 5 to $30 \%$ essential oil, 50 to $70 \%$ resin, 20 to $40 \%$ gummy material, and 1 to $10 \%$ moisture and minerals (Cross et al., 2007). This resin has potent antibacterial effects against gram-negative bacteria (Dorman and Deans, 2000).

The present study compared the effects of dietary addition of galbanum powder versus virginiamycin antibiotic on the performance, carcass characteristics, immune system, and blood factors of broiler chickens.

\section{Materials and Methods}

\section{Ethical considerations}

The experimental protocol was approved by the Animal Ethics Committee of Semnan University, Iran, and the experiment followed the International Guidelines For research Involving Animals (Directive 2019/63/EU).

\section{Animals and experimental design}

A total of 250 one-day old male broiler chickens (Ross 308) were used in a completely randomized design assigned to 25 experimental units. The chicks were assigned to five dietary treatments with five replicates. Each experimental unit consisted of 10 chickens with simmilar weight. The experimental treatments were: control (basal diet), virginiamycin (basal diet plus $0.1 \mathrm{~g}$ virginiamycin $/ \mathrm{kg}$ of diet), and three levels of galbanum powder $(2.5,5$ and $10 \mathrm{~g} /$ $\mathrm{kg}$ of diet). To prepare the powder, the top of the plant branches were collected dried and milled. Three corn-soybean basal diets were prepared compling with the nutrient requirements adviced by Ross Company (Ghazvinian et al., 2018). The experimental diets were: starter (1-10 days), grower (11-24 days) and finisher (25-42 days), in which the antibiotic and galbanum powder were added to the basal diet. The User-Friendly Feed 
Formulation, Done Again (UFFDA) software was used to formulate the diets. The composition of experimental diets is shown in Table 1.

\section{Performance}

Brooding conditions were the same for all the chickens throughout the experimental period and free access to feed and water was provided at all times (Poorghasemi et al., 2018). Feeds and chickens were weighed at the end of each period as well as for the whole period (42 days), and then feed intake, weight gain, and feed conversion ratio were determined (Poorghasemi et al., 2018).

\section{Carcass characteristics}

At the end of the experimental period (42 days), one chicken from each replicate was randomly selected (close to the mean weight), its digestive system removed after slaughtering, and the percentage of different body components (i.e., carcass, breast, thighs, gizzard, liver, heart, and abdominal fat) was calculated based on live weight.

\section{Lymphoid organ weight}

The percentage of spleen to body weight (relative weight) was measured at 42 days of age.

Table 1. Ingredients and nutrient composition of the experimental diets.

\begin{tabular}{lccc}
\hline Ingredients (\%) & Starter (1-10 days) & Grower (11-24 days) & Finisher (25-42 days) \\
\hline Corn & 49.03 & 51.01 & 57.29 \\
Soybean meal & 38.28 & 35.68 & 29.97 \\
Wheat bran & 3.00 & 3.00 & 3.00 \\
Canola oil & 5.00 & 6.35 & 6.00 \\
CaCO $_{3}$ & 1.42 & 1.15 & 1.15 \\
Dicalcium phosphate & 1.73 & 1.50 & 1.34 \\
DL-Methionine & 0.38 & 0.29 & 0.25 \\
L-Lysine-HCl & 0.33 & 0.17 & 0.15 \\
Salt & 0.33 & 0.35 & 0.35 \\
Mineral premix ${ }^{1}$ & 0.25 & 0.25 & 0.25 \\
Vitamin premix & 0.25 & 0.25 \\
\hline Chemical analyses & 0.25 & & \\
\hline Metabolizable energy (kcal/ & & 3,100 & \\
kg) & 2,980 & & 18.70 \\
Crude protein (\%) & & 20.66 & 0.83 \\
Ca (\%) & 21.63 & 0.88 & 0.40 \\
Available phosphorus (\%) & 1.03 & 0.44 & 1.07 \\
Lysine (\%) & 0.49 & 1.23 & 0.55 \\
Methionine (\%) & 1.41 & 0.61 & 0.84 \\
Methionine + cysteine (\%) & 0.71 & 0.93 & 0.75 \\
Threonine (\%) & 1.05 & 0.83 & \\
\hline
\end{tabular}

${ }^{1}$ Mineral mixture per kg of diet: MnSo4: $100 \mathrm{mg}$; I : $1 \mathrm{mg}$; CuSo4: $100 \mathrm{mg}$ and Fe: $50 \mathrm{mg}$.

${ }^{2}$ Vitamin premix per kg of diet: vitamin $\mathrm{A}: 11,000 \mathrm{IU}$; vitamin $\mathrm{D}_{3}: 23,000 \mathrm{IU}$; vitamin $\mathrm{E}: 121 \mathrm{IU}$; vitamin $\mathrm{K}_{3}: 2 \mathrm{mg}$; vitamin $\mathrm{B}_{6}: 4 \mathrm{mg}$; vitamin $\mathrm{B}_{12}: 0.020 \mathrm{mg}$; Thiamine: $4 \mathrm{mg}$; Riboflavin: $4 \mathrm{mg}$; Biotin: $0.03 \mathrm{mg}$; Nicotinic acid: 30,000 mg; Folic acid: $1 \mathrm{mg}$; Choline chloride: $840 \mathrm{mg}$ and Ethoxyquin: 0.125. 


\section{Response to Newcastle disease virus vaccine}

Newcastle disease vaccine was given to the chickens at 19 days of age. At 42 days of age, two birds were randomly selected from each replicate and $1 \mathrm{~mL}$ of blood was taken from a wing vein. Blood serum was separated by centrifuging the samples at 3,000 rpm for 15 minutes. The serum was specified in terms of Newcastle anti-virus antibodies by the Hemagglutination Inhibition (HI) assay (Dorman and Deans, 2000).

\section{Response to sheep red blood cell (SRBC)}

At 28-day of age two chickens from each experimental unit were injected $0.2 \mathrm{ml}$ of washed 5\% suspension of sheep red blood cells in sterile phosphate buffer through the breast muscle to evaluate the effects of the treatments on specific immune responses. Blood samples were collected from the wing vein 14 days after injection (42 days of age) and blood serum was isolated by centrifugation at $3,000 \mathrm{rpm}$ for 15 minutes. The concentration of anti-SRBC antibody was assessed by hemmaglutination assay (Poorghasemi et al., 2015).

\section{Blood factors}

At 42 days of age, two chickens were randomly selected per replicate and blood samples were taken from their wing veins. Then, blood serum was used to determine the concentration of total protein, albumin, globulin, cholesterol, triglycerides, LDL, and HDL. The concentration of those factors was measured using biochemistry kits and a calorimetric enzyme assay (VaseKhavari et al., 2019).

\section{Statistical analysis}

Data were analyzed using the general linear model (GLM) of the SAS software, version 9.4 (SAS Institute, Cary, NC, USA; 2019) and mean comparisons were performed using Duncan's multi-domain test at 5\% probability level. The statistical model was $\mathrm{Yij}=\mu+\mathrm{Ai}+$ eij, where: Yij is the measured attribute value, $\mu$ is the mean of the trait in the target population, $\mathrm{Ai}$ is the effect of treatment, and eij is the effect of the test error.

\section{Results}

Tables 2, 3 and 4 show the effect of experimental groups on the performance of broilers (body weight gain, feed intake, and feed conversion ratio). In the starter period, there was no significant difference in weight gain among treatments $(p<0.05)$. During the grower period, weight gains in all treatments were different compared to the control $(p<0.05)$. The treatment containing $10 \mathrm{~g}$ galbanum resulted in the highest weight gain. In the finisher period and during the whole period, the weight gain of the treatments containing 5 and $10 \mathrm{~g}$ galbanum increased compared to the control $(p<0.05)$.

In the starter and finisher periods, feed intake was simmilar compared to the control $(p>0.05)$. In the grower period, the differences in feed intake among treatments were significant compared to the control $(p<0.05)$. Feed intake of broilers fed galbanum-containing diets was higher than the control and antibiotic-containing treatment. In the entire period, feed intake of treatments containing 5 or $10 \mathrm{~g}$ galbanum increased compared to the control $(p<0.05)$. In contrast, feed intake of treatments containing 2.5 $\mathrm{mg}$ galbanum or antibiotic were lower than that of the control $(p<0.05)$. In the grower period, the conversion ratio of treatments containing galbanum showed difference compared to the control $(p<0.05)$. In the finisher period, the conversion of all treatments decreased compared to the control $(p<0.05)$. In the whole period, the conversion of treatments containing 2.5 or $5 \mathrm{~g}$ galbanum and also the treatment containing antibiotic showed a significant decrease compared to the control $(p<0.05)$.

\section{Carcass composition}

The effects of galbanum and antibiotic on carcass components are shown in Table 5. No significant difference was found for the percentage of carcass, breast, and thigh in any of the treatments compared to the control $(p>0.05)$. The percentage of gizzard in all treatments did not significantly differ compared to the control $(p>0.05)$. In contrast, gizzard weight 
of galbanum-containing treatments increased compared to the antibiotic-containing treatment $(p<0.05)$. The percentage of liver and ventricular fat in treatments containing 5 and $10 \mathrm{~g}$ galbanum decreased compared to the control and antibioticcontaining treatment $(p<0.05)$. Heart weight in all treatments containing galbanum decreased compared to the control and antibiotic-containing treatment $(p<0.05)$

\section{Immune system}

The effects of the treatments on the immune system are presented in Table 6 . The weight of spleen in the treatments containing 5 or $10 \mathrm{~g}$ galbanum increased compared to the control and antibiotic-containing treatment $(p<0.05)$.

Table 2. Effects of virginiamycin and galbanum on body weight gain $(\mathrm{g})$ of broiler chickens.

\begin{tabular}{lcccc}
\hline Treatments & Starter (1-10 days) & Grower $(\mathbf{1 1 - 2 4}$ days) & Finisher (25-42 days) & Whole (1-42 days) \\
\hline Basal diet (control) & $216.56 \pm 1.03^{\mathrm{a}}$ & $589.44 \pm 0.88^{\mathrm{c}}$ & $1186.26 \pm 1.47^{\mathrm{c}}$ & $2001.0 \pm 1.08^{\mathrm{c}}$ \\
Virginiamycin $(0.1 \mathrm{~g} / \mathrm{kg}$ diet) & $215.38 \pm 1.03^{\mathrm{a}}$ & $595.47 \pm 1.27^{\mathrm{b}}$ & $1186.98 \pm 0.89^{\mathrm{c}}$ & $2001.9 \pm 0.91^{\mathrm{c}}$ \\
Galbanum $(2.5 \mathrm{~g} / \mathrm{kg}$ diet) & $215.52 \pm 0.90^{\mathrm{a}}$ & $598.5 \pm 1.06^{\mathrm{b}}$ & $1189.19 \pm 1.23^{\mathrm{bc}}$ & $2002.3 \pm 1.18^{\mathrm{c}}$ \\
Galbanum $(5 \mathrm{~g} / \mathrm{kg} \mathrm{diet})$ & $216.58 \pm 0.92^{\mathrm{a}}$ & $608.58 \pm 1.54^{\mathrm{a}}$ & $1191.45 \pm 1.47^{\mathrm{b}}$ & $2011.4 \pm 0.96^{\mathrm{b}}$ \\
Galbanum $(10 \mathrm{~g} / \mathrm{kg} \mathrm{diet})$ & $216.58 \pm 0.92^{\mathrm{a}}$ & $610.73 \pm 1.46^{\mathrm{a}}$ & $1196.73 \pm 1.92^{\mathrm{a}}$ & $2016.7 \pm 1.24^{\mathrm{a}}$ \\
\hline SEM & 1.03 & 1.24 & 1.39 & 1.07 \\
\hline
\end{tabular}

Means within the same column with at least one common letter, are not significantly different $(p<0.05)$.

SEM: standard error of the mean.

Table 3. Effects of virginiamycin and galbanum on feed intake ( $\mathrm{g} / \mathrm{hen} /$ period) of broiler chickens.

\begin{tabular}{lcccc}
\hline Treatments & Starter (1-10 days) & Grower $(\mathbf{1 1 - 2 4}$ days) & Finisher (25-42 days) & Whole (1-42 days) \\
\hline Basal diet (control) & $366.0 \pm 1.11^{\mathrm{ab}}$ & $1,173.0 \pm 1.57^{\mathrm{e}}$ & $2,444.0 \pm 0.94^{\mathrm{a}}$ & $4,007.4 \pm 1.40^{\mathrm{c}}$ \\
Virginiamycin $(0.1 \mathrm{~g} / \mathrm{kg}$ diet) & $364.0 \pm 1.18^{\mathrm{b}}$ & $1,185.0 \pm 1.18^{\mathrm{d}}$ & $2,444.0 \pm 1.39^{\mathrm{a}}$ & $3,981.6 \pm 1.26^{\mathrm{e}}$ \\
Galbanum (2.5 g/kg diet) & $366.0 \pm 1.00^{\mathrm{ab}}$ & $1,197.0 \pm 1.29^{\mathrm{c}}$ & $2,444.0 \pm 0.81^{\mathrm{a}}$ & $3,993.0 \pm 2.12^{\mathrm{d}}$ \\
Galbanum $(5 \mathrm{~g} / \mathrm{kg} \mathrm{diet)}$ & $364.60 \pm 1.04^{\mathrm{b}}$ & $1,205.0 \pm 1.34^{\mathrm{b}}$ & $2,444.0 \pm 1.21^{\mathrm{a}}$ & $4,015.0 \pm 1.20^{\mathrm{b}}$ \\
Galbanum (10 g/kg diet) & $368.2 \pm 0.99^{\mathrm{a}}$ & $1,252.0 \pm 1.75^{\mathrm{a}}$ & $2,444.03 \pm 1.26^{\mathrm{a}}$ & $4,064.2 \pm 1.61^{\mathrm{a}}$ \\
\hline SEM & 1.06 & 1.42 & 1.12 & 1.51 \\
\hline
\end{tabular}

Means within the same column with at least one common letter, are not significantly different $(p<0.05)$.

SEM: standard error of the mean.

Table 4. Effects of virginiamycin and galbanum on feed conversion ratio (feed: gain) of broiler chickens.

\begin{tabular}{lcccc}
\hline Treatments & Starter (1-10 days) & Grower $(\mathbf{1 1 - 2 4}$ days) & Finisher $\mathbf{( 2 5 - 4 2}$ days) & Whole (1-42 days) \\
\hline Basal diet (control) & $1.69 \pm 0.05^{\mathrm{b}}$ & $1.99 \pm 0.08^{\mathrm{c}}$ & $2.06 \pm 1.14^{\mathrm{a}}$ & $2.00 \pm 1.00^{\mathrm{b}}$ \\
Virginiamycin $(0.1 \mathrm{~g} / \mathrm{kg}$ diet) & $1.69 \pm 0.05^{\mathrm{b}}$ & $1.99 \pm 0.08^{\mathrm{c}}$ & $2.05 \pm 1.11^{\mathrm{b}}$ & $1.98 \pm 0.08^{\mathrm{d}}$ \\
Galbanum $(2.5 \mathrm{~g} / \mathrm{kg}$ diet) & $1.70 \pm 0.1^{\mathrm{b}}$ & $2.00 \pm 1.13^{\mathrm{b}}$ & $2.05 \pm 1.11^{\mathrm{b}}$ & $1.99 \pm 0.08^{\mathrm{c}}$ \\
Galbanum $(5 \mathrm{~g} / \mathrm{kg} \mathrm{diet})$ & $1.69 \pm 0.05^{\mathrm{b}}$ & $1.098 \pm 0.07^{\mathrm{d}}$ & $2.05 \pm 1.11^{\mathrm{b}}$ & $1.99 \pm 0.08^{\mathrm{c}}$ \\
Galbanum $(10 \mathrm{~g} / \mathrm{kg}$ diet) & $1.70 \pm 0.1^{\mathrm{b}}$ & $2.05 \pm 1.15^{\mathrm{b}}$ & $2.04 \pm 1.12 \mathrm{c}$ & $2.01 \pm 1.00^{\mathrm{a}}$ \\
\hline SEM & 0.07 & 0.50 & 1.11 & 0.40 \\
\hline
\end{tabular}

Means within the same column with at least one common letter, are not significantly different $(p<0.05)$.

SEM: standard error of the mean. 
The immune response against Newcastle disease virus and SRBC for the treatment containing $10 \mathrm{~g}$ galbanum at 42 days of age increased compared to the control and the other treatments $(p<0.05)$.

\section{Blood factors}

The effects of treatment on several blood parameters of broilers at the end of the experiment (42 days) are presented in Table 7. There were no significant changes in the levels of blood biochemical parameters for the treatment containing antibiotic compared to the control ( $\mathrm{p}>0.05)$. By adding $10 \mathrm{~g}$ galbanum in the diet, levels of serum protein variables (total protein, albumin, and globulin) increased compared to the control and the other treatments $(p<0.05)$. Also, serum lipid values (cholesterol, triglyceride, and LDL) in galbanum-containing treatments decreased compared to the control and the antibiotic-containing treatments $(p<0.05)$. Serum HDL concentration of broilers treated with galbanum increased compared to the control and the antibiotic treatment $(p<0.05)$.

\section{Discussion}

Acording to our results, adding galbanum powder to the diet of broiler chickens increased body weight gain and feed intake in the grower, finisher, and the overall period.

Table 5. Effects of virginiamycin and galbanum on carcass characteristics of broiler chickens.

\begin{tabular}{|c|c|c|c|c|c|c|c|}
\hline Treatments & $\begin{array}{c}\text { Carcass } \\
(\%)\end{array}$ & Breast (\%) & Thigh (\%) & Gizzard (\%) & Liver (\%) & Heart (\%) & $\begin{array}{l}\text { Abdominal } \\
\text { fat }(\%)\end{array}$ \\
\hline Basal diet (control) & $73.72 \pm 0.72^{\mathrm{a}}$ & $26.92 \pm 0.58^{\mathrm{a}}$ & $19.84 \pm 0.54^{\mathrm{a}}$ & $1.36 \pm 0.015^{\mathrm{bc}}$ & $2.19 \pm 0.025^{\mathrm{ab}}$ & $0.51 \pm 0.003^{\mathrm{a}}$ & $1.38 \pm 0.018^{\mathrm{ab}}$ \\
\hline $\begin{array}{l}\text { Virginiamycin (0.1 } \\
\mathrm{g} / \mathrm{kg} \text { diet) }\end{array}$ & $72.85 \pm 0.84^{\mathrm{a}}$ & $25.87 \pm 0.49^{a}$ & $19.00 \pm 0.71^{\mathrm{a}}$ & $1.33 \pm 0.009^{c}$ & $2.23 \pm 0.013^{\mathrm{a}}$ & $0.51 \pm 0.0005^{\mathrm{a}}$ & $1.43 \pm 0.18^{\mathrm{a}}$ \\
\hline $\begin{array}{l}\text { Galbanum ( } 2.5 \mathrm{~g} / \\
\mathrm{kg} \text { diet })\end{array}$ & $73.38 \pm 0.96^{\mathrm{a}}$ & $26.31 \pm 0.71^{\mathrm{a}}$ & $19.14 \pm 0.50^{\mathrm{a}}$ & $1.37 \pm 0.008^{\mathrm{b}}$ & $2.16 \pm 0.012^{\mathrm{b}}$ & $0.49 \pm 0.001^{\mathrm{b}}$ & $1.38 \pm 0.013^{\mathrm{b}}$ \\
\hline $\begin{array}{l}\text { Galbanum }(5 \mathrm{~g} / \mathrm{kg} \\
\text { diet) }\end{array}$ & $73.50 \pm 0.77^{\mathrm{a}}$ & $26.53 \pm 0.27^{\mathrm{a}}$ & $19.23 \pm 0.37^{\mathrm{a}}$ & $1.38 \pm 0.01^{\mathrm{b}}$ & $1.98 \pm 0.022^{\mathrm{d}}$ & $0.49 \pm 0.0003^{\mathrm{b}}$ & $1.28 \pm 0.017^{\mathrm{c}}$ \\
\hline $\begin{array}{l}\text { Galbanum (10 g/ } \\
\mathrm{kg} \text { diet) }\end{array}$ & $74.63 \pm 0.40^{\mathrm{a}}$ & $27.47 \pm 0.70^{\mathrm{a}}$ & $20.73 \pm 0.61^{\mathrm{a}}$ & $1.38 \pm 0.009^{\mathrm{b}}$ & $2.07 \pm 0.007^{\mathrm{c}}$ & $0.49 \pm 0.0008^{b}$ & $1.31 \pm 0.012^{\mathrm{c}}$ \\
\hline SEM & 0.73 & 0.55 & 0.54 & 0.01 & 0.015 & 0.010 & 0.048 \\
\hline
\end{tabular}

Means within the same column with at least one common letter, are not significantly different $(p<0.05)$.

SEM: standard error of the mean.

Table 6. Effects of virginiamycin and galbanum on the immune system of broiler chickens.

\begin{tabular}{lccc}
\hline Treatments & Spleen (\%) & $\begin{array}{c}\text { Immune response after } \\
\text { Newcastle vaccination }\end{array}$ & $\begin{array}{c}\text { Immune response after } \\
\text { SRBC }\end{array}$ \\
\hline Basal diet (control) & $0.117 \pm 0.0006^{\mathrm{cd}}$ & $3.00 \pm 0.29^{\mathrm{b}}$ & $3.00 \pm 0.31^{\mathrm{b}}$ \\
Virginiamycin $(0.1 \mathrm{~g} / \mathrm{kg} \mathrm{diet})$ & $0.116 \pm 0.0006^{\mathrm{d}}$ & $3.00 \pm 0.39^{\mathrm{b}}$ & $3.20 \pm 0.37^{\mathrm{b}}$ \\
Galbanum $(2.5 \mathrm{~g} / \mathrm{kg} \mathrm{diet)}$ & $0.119 \pm 0.0008^{\mathrm{c}}$ & $3.70 \pm 0.33^{\mathrm{b}}$ & $3.40 \pm 0.24^{\mathrm{b}}$ \\
Galbanum (5 g/kg diet) & $0.121 \pm 0.0008^{\mathrm{b}}$ & $4.00 \pm 0.25^{\mathrm{b}}$ & $3.80 \pm 0.37^{\mathrm{b}}$ \\
Galbanum (10 g/kg diet) & $0.124 \pm 0.0005^{\mathrm{a}}$ & $5.00 \pm 0.33^{\mathrm{a}}$ & $5.00 \pm 0.31^{\mathrm{a}}$ \\
SEM & 0.0006 & 0.31 & 0.32 \\
\hline
\end{tabular}

Means within the same column with at least one common letter, are not significantly different $(p<0.05)$.

SEM: standard error of the mean. 
Table 7. Effects of virginiamycin and galbanum on blood factors of broiler chickens.

\begin{tabular}{lccccccc}
\hline Treatments & $\begin{array}{c}\text { Cholesterol } \\
(\mathbf{m g} / \mathbf{d L})\end{array}$ & $\begin{array}{c}\text { Triglyceride } \\
(\mathbf{m g} / \mathbf{d L})\end{array}$ & $\begin{array}{c}\text { LDL } \\
(\mathbf{m g} / \mathbf{d L})\end{array}$ & $\begin{array}{c}\text { HDL } \\
(\mathbf{m g} / \mathbf{d L})\end{array}$ & $\begin{array}{c}\text { Total protein } \\
(\mathbf{g} / \mathbf{d L})\end{array}$ & $\begin{array}{c}\text { Albumin } \\
(\mathbf{g} / \mathbf{d L})\end{array}$ & $\begin{array}{c}\text { Globulin } \\
(\mathbf{g} / \mathbf{d L})\end{array}$ \\
\hline $\begin{array}{l}\text { Basal diet }(\text { control) } \\
\text { Virginiamycin }(0.1\end{array}$ & $184.29 \pm 1.05^{\mathrm{a}}$ & $111.32 \pm 1.70^{\mathrm{a}}$ & $73.56 \pm 0.94^{\mathrm{a}}$ & $24.77 \pm 0.77^{\mathrm{d}}$ & $3.29 \pm 0.06^{\mathrm{b}}$ & $2.20 \pm 0.04^{\mathrm{bc}}$ & $1.09 \pm 0.04^{\mathrm{bc}}$ \\
g/kg diet) & $184.39 \pm 1.06^{\mathrm{a}}$ & $111.32 \pm 1.73^{\mathrm{a}}$ & $60.20 \pm 0.63^{\mathrm{b}}$ & $24.53 \pm 0.55^{\mathrm{d}}$ & $3.25 \pm 0.07^{\mathrm{b}}$ & $2.13 \pm 0.02^{\mathrm{bc}}$ & $1.06 \pm 0.50^{\mathrm{c}}$ \\
$\begin{array}{l}\text { Galbanum }(2.5 \mathrm{~g} / \\
\text { kg diet) }\end{array}$ & $161.98 \pm 2.05^{\mathrm{b}}$ & $93.87 \pm 1.70^{\mathrm{b}}$ & $58.18 \pm 0.91^{\mathrm{b}}$ & $30.03 \pm 0.55^{\mathrm{c}}$ & $3.25 \pm 0.03^{\mathrm{b}}$ & $2.03 \pm 0.09^{\mathrm{c}}$ & $1.12 \pm 0.02^{\mathrm{b}}$ \\
$\begin{array}{l}\text { Galbanum }(5 \mathrm{~g} / \mathrm{kg} \\
\text { diet) }\end{array}$ & $136.23 \pm 1.31^{\mathrm{c}}$ & $86.94 \pm 1.07^{\mathrm{c}}$ & $40.81 \pm 1.10^{\mathrm{c}}$ & $36.00 \pm 0.60^{\mathrm{b}}$ & $3.27 \pm 0.04^{\mathrm{b}}$ & $2.19 \pm 0.06^{\mathrm{b}}$ & $1.12 \pm 0.03^{\mathrm{b}}$ \\
$\begin{array}{l}\text { Galbanum }(10 \mathrm{~g} / \\
\text { kg diet) }\end{array}$ & $115.79 \pm 2.14^{\mathrm{d}}$ & $76.56 \pm 1.84^{\mathrm{d}}$ & $42.38 \pm 1.59^{\mathrm{c}}$ & $40.83 \pm 0.62^{\mathrm{a}}$ & $3.72 \pm 0.08^{\mathrm{a}}$ & $2.43 \pm 0.05^{\mathrm{a}}$ & $1.29 \pm 0.04^{\mathrm{a}}$ \\
\hline SEM & 1.58 & 1.42 & 1.03 & 0.61 & 0.05 & 0.07 & 0.04 \\
\hline
\end{tabular}

Means within the same column with at least one common letter, are not significantly different $(p<0.05)$.

SEM: standard error of the mean.

This increase was higher than that of the virginiamycin-containing treatment. Also, feed conversion ratio improved by galbanum addition to the diet, and this improvement was higher compared with the antibiotic-containing treatment. These results are inconsistent with the report by Hernandez et al. (2004) who observed that medicinal plants and their extracts did not affect feed intake. They stated that the addition of mint leaves to the diet did not have a significant effect on poultry performance. Cross et al. (2007) reported that feeding medicinal plants at concentrations of 1 and $0.1 \%$ increased body weight and feed intake, and improved feed conversion ratio compared to the control, which was probably due to the antibacterial and antifungal effects of mint. The positive effects on body weight using essential oils in the diet have also been observed in other studies (Abudabos et al., 2017). The use of herbal medicines in the diet increased the body weight of broiler chickens by $3 \%$ at 42 days of age (Tiihonen et al., 2010). The effect of herbal ingredients may be due to increased nutrient utilization that improve poultry growth. Also, the increase of appetite, stimulation of digestive secretions and antibacterial effects are among the mechanisms that can be responsible for performance improvement (Tiihonen et al., 2010). Using a mixture of effective oils from several wild medicinal plants for broiler chickens resulted in improved conversion ratio compared to the control and the antibiotic-containing treatment (Alçiçek et al., 2003). It has been suggested that herbal ingredients can improve feed conversion through better nutrient utilization due to increased digestive enzymes and improved ileal digestibility (Isabel and Santos, 2009). According to our results, feed conversion for the whole period in the antibiotic-containing treatment was lower than the control and the other treatments due to a reduced feed intake. It has been reported that the antibiotic effect on broiler performance is due to decreased feed intake per unit of weight gain, resulting in improved feed conversion ratio (Alhidary et al., 2016).

According to our results, the percentage of carcass, breast, thigh, and gizzard in galbanumcontaining treatments was not different compared to the control, though it was numerically higher compared to the antibiotic-containing treatment. The compounds in medicinal herbs have a microbicidal effect and, by decreasing the microbial population in the digestive tract, prevent amino acid degradation, increase their absorption and improve carcass traits (Nobakht et al., 2015). The presence of high levels of microbial mass in the digestive system results in protein and amino acid degradation through deamination, thus significant amounts of amino 
acids and proteins are not decomposed and not absorbed (Lee et al., 2003). Additionaly, when harmful microbial populations are reduced, the conditions for growth and proliferation of beneficial microbes are provided and the health of the chickens improves, leading to optimized digestion and absorption and improved carcass traits (Lee et al., 2003). The lack of difference in carcass, breast, and thigh percentage in the present study may be due to the fact that proper sanitary breeding conditions were provided, thus the activity of harmful microbes was not up to a limit as to allow galbanum and antibiotic to considerably affect carcass components in comparison with the control.

Based on our results, while the relative weight of the liver increased by increasing galbanum levels, the liver percentage in the 5 and $10 \mathrm{~g}$ galbanum treatments decreased compared to the control, which is consistent with the report of Nasiri et al. (2011). It has been reported that $0.5 \%$ herbal addition to the diet not only result in increased liver size but also reduce its size relative to the control diet (Galiband Alkassie, 2010). The liver is the target organ for toxins, which can cause liver toxicity and affect its weight (Galiband Al-kassie, 2010). Since galbanum has toxic effects due to its alphathujene compound, it can increase liver size by hypertrophy of the smooth endoplastic reticulum in the hepatocyte (Sayyah et al., 2001). While the long term use of high doses of herbal drugs can have deleterious effects on the liver, the use of low doses result in low toxicity and improves organ function due to its antioxidant properties (Ocak et al., 2008), which could explain the decrease in liver percentage compared to the control in the present study.

Heart weight decreased significantly in galbanum-containing treatments compared to the other treatments, which is consistent with the results of Cross et al. (2007). Thymol and phenolic compounds present in medicinal plants have antimicrobial and antifungal activity and are considered antioxidants and growth stimulants (Cross et al., 2007).
Regarding the theory that lipid peroxidation may cause heart tissue damage and blood pressure syndrome, the role of medicinal plants with antioxidant properties has been widely investigated. Ciftci et al.(2010) found that adding $5 \mathrm{~g}$ of medicinal herbs with antioxidant properties per kilogram of diet reduces the thickness of the outer wall of arteries, which subsequently decreases the resistance to blood flow, thus reducing the size of the heart. Furthermore, Ruiz-Feria (2009) reported that $5 \mathrm{ml}$ of lemon balm essential oil in the diet of broilers significantly reduced heart weight. Increasing the antioxidant capacity, especially in tissues involved with ascites such as myocardium cells, can create an antioxidant protective effect, stop peroxidation of the capillary membrane lipid tissue, and prevent the hypertrophy of heart ventricles. It is possible that galbanum antioxidant could prevent cellular peroxidation in the heart tissue and inhibit its growth (Geng et al., 2004b).

It has been reported that the addition of medicinal plants to the diet of broilers results in decreased abdominal fat due to increased secretion of pancreatic enzymes (Jamroz et al., 2005). This effect has also been attributed to inhibition of liver enzymes involved in lipogenesis or lipoprotein lipase present in the fat tissue (Gavanji et al., 2014).

Plant additives can increase the relative weight of the spleen (Moorthy et al., 2009), which is consistent with this study. Medicinal plants are rich in flavonoids and terpenes, which indirectly enhance and stimulate the immune system with their antibacterial effects. When the immune system is stimulated, the spleen size and protein synthesis increases, leading to refining and activation of the immune system in response to the disease (Nasiroleslami and Torki, 2010). Regarding the high titer of antibodies against Newcastle Virus and SRBC in galbanum-containing treatments in the present study, the plant effectively boosted the immune system compared to the antibiotic, which is consistent with Feizi and Nazari (2011) and Ghalamkari et al. (2011). The response rate 
of the immune system varies based on genetic variation (Webster et al., 2006). In addition to genetic factors, non-genetic factors such as diet supplements that affect growth, can change or modify the expression of the genes responsible for immune sensitivity by altering antibody production and immune maturation. Herbal medicines eliminate harmful bacteria in the intestines, help the digestive system to better absorb dietary nutrients and cause further growth of cells, which consequently increases the production of immunization compounds (Okoro et al., 2016). Various compounds in medicinal plants can stimulate lymphoid organs due to their nutritional and antioxidant effects. They can contribute to amplification and proliferation of chicken embryonic fibroblast cells that play a role in the development of the immune system and bone marrow (Mahanta et al., 2017). Regarding the effects of medicinal plants on broiler immunity, they can increase the percentage of lymphocytes and heterophile, indicating their beneficial effects on immunity (Al-Jaff, 2011; Nacimento et al., 2020). Additionally, free radicals is an important mechanism of cell damage (Kumar et al., 2003).

The high level of total protein, albumin, and globulin in the $10 \mathrm{~g}$ galbanum treatment can be attributed to the increased nutrient absorption such as protein and its presence in blood serum. It has been reported that galbanum powder reduces the harmful gastrointestinal microbial populations and, therefore, the degradation of protein and amino acids. As a result, absorption increases, improving nutrient digestibility and serum concentration of total protein, albumin, and globulin (Lee et al., 2003; Ghazvinian et al., 2018).

A decrease in total cholesterol, triglyceride and LDL levels, as well as a significant increase in HDL in the treatments containing galbanum compared to the control and antibiotic-containing treatment demonstrates the effectiveness of the plant in modifying blood lipids. Abdel-Hafez et al. (2017) stated that the decrease in abdominal fat is due to increased populations of beneficial bacteria such as Bacillus subtilis. These bacteria further reduce the activity of acetyl coenzyme A carboxylase by excreting bile acids, thereby reducing the synthesis of fatty acids and their availability for esterification reactions and production of triglycerides for storage in the adipose tissue.

The role of medicinal plants in reducing cholesterol and triglycerides (Hosseini et al., 2013) is consistent with our results. Supplementation can be effective in lowering cholesterol levels due to the activity of lactic acid bacteria by producing bile-degrading enzymes and their deconjugation, as well as by decreasing the $\mathrm{pH}$ of the intestinal tract (Jahromi et al., 2016). Solubility of unconjugated bile acids decreases at low $\mathrm{pH}$, resulting in less intestinal absorption and more excretion in the stools (Jahromi et al., 2016). As a result, the liver converts more cholesterol into bile to rebuild the cycle of bile acids, hence decreasing the concentration of cholesterol in tissues and blood (Ali et al., 2007). Herbal ingredients inhibit the activity of 3-hydroxyl 3-methylglutaryl-coenzyme A (HMG-COA) liver reductase (Souri et al., 2015). This is a key enzyme in the regulation of cholesterol synthesis. As it has been reported, there is a link between the activity of HMG-COA reductase, serum cholesterol and lipoproteins in broilers (Iqbal et al., 2018). 5\% HMG-COA reductase inhibitory activity can reduce serum cholesterol, triglyceride and LDL of poultry by $1 \%$ and also increase HDL (Safa and Al-Beitawi, 2009). Jeong and Kim (2015) tested the hypothesis that a medicinal herb used in the diet could restrain the biosynthesis of isopentenyl pyrophosphate, a precursor to cholesterol synthesis. Ajuwon (2016) reported that poultry diets containing medicinal plants increased the microbial population of lactobacilli in the intestine and these lactobacilli can metabolize and absorb cholesterol in the small intestine and also reduce its absorption to the bloodstream.

Rostami et al. (2020) investigated the effects of Thymus vulgaris extract in comparison with some common feed additives on performance, blood biochemical parameters and antibody 
response of broiler chickens under heat stress. They suggested that thyme extract at $500 \mathrm{mg} /$ $\mathrm{kg}$ of diet can be an alternative to common feed additives to improve growth performance and health benefits of heat-stressed broilers.

The present study shows that dietary inclusion of galbanum powder is effective in improving performance and carcass characteristics of broilers, increasing the immune response without adverse effects on blood parameters.

\section{Declarations}

\section{Acknowledgments}

The authors wish to acknowledge support from Department of Animal Science, Semnan University, Semnan, Iran.

\section{Funding}

This study was conducted with personal funding by the authors.

\section{Conflicts of interest}

The authors declare they have no conflicts of interest with regard to the work presented in this report.

\section{Author contributions}

All authors contributed extensively to all aspects of this work, including the conception and design of the study, implementation, data analysis and manuscript writing.

\section{References}

Abedi D, Jalali M, Asghari G, Sadeghi N. Composition and antimicrobial activity of oleo gumresin of Ferula gummosa bioss. essential oil using Alamar Blue ${ }^{\mathrm{TM}}$. Res Pharm Sci 2008; 3(1): 41-45.

Abdel-Hafeez HM, Saleh ESE, Tawfeek SS, Youssef IMI, Abdel-Daim ASA. Effects of probiotic, prebiotic, and synbiotic with and without feed restriction on performance, hematological indices and carcass characteristics of broiler chickens. Asian- australas J Anim Sci 2017; 30(5): 672-682. https://doi.org/10.5713/ajas.16.0535

Abudabos AM, Alyemni AH, Dafalla YM, Khan RU. Effect of organic acid blend and Bacillus subtilis alone or in combination on growth traits, blood biochemical and antioxidant status in broilers exposed to Salmonella typhimurium challenge during the starter phase. J Appl Anim Res 2017; 45(1): 538-542. https://doi.org/10.1080/09712119.2016.1219665

Adaszyńska-Skwirzyńska M, Szczerbińska D. The effect of lavender (Lavandula angustifolia) essential oil as a drinking water supplement on the production performance, blood biochemical parameters, and ileal microflora in broiler chickens. Poult 2019; 98(1): 358-365. https://doi.org/10.3382/ps/pey385

Ahmadi M, Ahmadian A, Poorghasemi M, Makovicky P, Seidavi A. Nano-Selenium affects on duodenum, jejunum, ileum and colon characteristics in chicks: An animal model. Int $\mathbf{J}$ Nano Dimens 2019; 10(2): 225-229.

Ajuwon KM. Toward a better understanding of mechanisms of probiotics and prebiotics action inpoultry species. J Appl Poult Res 2016; 25(2): 277-283. https://doi.org/10.3382/japr/pfv074

Al-Jaff FK. Effect of coriander seeds as diet ingredient on blood parameters of broiler chicks raised under high ambient temperature.

Int J Poult Sci 2011; 10(2): 82-86. https://doi.org/10.3923/ijps.2011.82.86

Alcicek AH, Bozkurt M, Çabuk M. The effect of an essential oil combination derived from selected herbs growing wild in Turkey on broiler performance. SAfr JAnim Sci 2003; 33(2): 89-94. https://doi.org/10.4314/sajas.v33i2.3761

Alhidary IA, Abdelrahman MM, Khan RU. Comparative effects of direct-fed microbials alone or with a trace minerals supplements on the productive performance, blood metabolites, and antioxidantstatusingrazingAwassilambs. Environ Sci Pollut Res 2016; 23(24): 25218-25223. https://doi.org/10.1007/s11356-016-7684-z 
Ali MN, Hassan MS, Abd El-Ghany FA. Effect of strain, type of natural antioxidant and sulphate ion on productive, physiological and hatching performance of native laying hens. Int J Poult Sci 2007; 6(8): 539-554. https://doi.org/10.3923/ijps.2007.539.554

Chen YJ, Kim IH, Cho JH, Yoo JS, Wang Q, Wang Y, Huang Y. Evaluation of dietary L-carnitine or garlic powder on growth performance, dry matter and nitrogen digestibilities, blood profiles and meat quality in finishing pigs. Anim Feed Sci Technol 2008; 141(1-2): 141-152. DOI: https://doi.org/10.1016/j.anifeedsci.2007.05.025

Ciftci M, Simsek UG, Yuce A, Yilmaz O, Dalkilic B. Effects of dietary antibiotic and cinnamon oil supplementation on antioxidant enzyme activities, cholesterol levels and fatty acid compositions of serum and meat in broiler chickens. Acta Vet Brno 2010; 79(1): 33-40. https://doi.org/10.2754/avb201079010033

Cross DE, McDevitt RM, Hillman K, Acamovic T. The effect of herbs and their associated essential oils on performance, dietary digestibility and gut microflora in chickens from 7 to 28 days of age. $\mathrm{Br} 2007$; 48(4): 496-506. https://doi.org/10.1080/00071660701463221

Dorman HD, Deans SG. Antimicrobial agents from plants: antibacterial activity of plant volatile oils. J Appl Microbiol 2000; 88(2): 308-316. https://doi.org/10.1046/j.1365-2672.2000.00969.x

Feizi A, Nazeri M. The effect of thyme essential oils (Thymus vulgaris) in the vaccination reactions on broiler chicks. Adv Environ Biol 2011; 1912-1916.

Al-Kassie GA. The role of peppermint (Mentha piperita) on performance in broiler diets. ABJNA 2010; 1(5): 1009-1013. https://doi.org/10.5251/abjna.2010.1.5.1009.1013

Gavanji S, Larki B, Bakhtari A. The effect of extract of Punica granatum var. pleniflora for treatment of minor recurrent aphthous stomatitis. Intregr Med 2014; 3(2): 83-90. https://doi.org/10.1016/j.imr.2014.03.001
Geng AL, Guo YM, Yang Y. Reduction of ascites mortality in broilers by coenzyme Q10. Poult 2004; 83(9): 1587-1593. https://doi.org/10.1093/ps/83.9.1587

Ghalamkari G, Toghyani M, Tavalaeian E, Landy N, Ghalamkari Z, Radnezhad H. Efficiency of different levels of Satureja hortensis L.(Savory) in comparison with an antibiotic growth promoter on performance, carcass traits, immune responses and serum biochemical parameters in broiler chickens. Afr J Biotechnol 2011; 10(61): 13318-13323. https://doi.org/10.5897/AJB11.911

Ghazvinian K, Seidavi A, Laudadio V, Ragni M, Tufarelli V. Effects of various levels of organic acids and of virginiamycin on performance, blood parameters, immunoglobulins and microbial population of broiler chicks. S Afr J Anim Sci 2018; 48(5): 961-967. https://doi.org/10.4314/sajas.v48i5.16

Greathead H. Plants and plant extracts for improving animal productivity. Proc Nutr Soc 2003; 62(2): 279-290. https://doi.org/10.1079/pns2002197

Hernandez F, Madrid J, Garcia V, Orengo J, Megias MD. Influence of two plant extracts on broilers performance, digestibility, and digestive organ size. Poult 2004; 83(2): 169-174. https://doi.org/10.1093/ps/83.2.169

Hosseini SA, Meimandipour A, Alami F, Mahdavi A, Mohiti-AsliM,Lotfollahian H, Cross D. Effects of ground thyme and probiotic supplements in diets on broiler performance, blood biochemistry and immunological response to sheep red blood cells. Ital J Anim Sci 2013; 12(1): e19. https://doi.org/10.4081/ijas.2013.e19

Iqbal Z, Roberts J, Perez-Maldonado RA, Goodarzi Boroojeni F, Swick RA, Ruhnke I. Pasture, multi-enzymes, benzoic acid and essential oils positively influence performance, intestinal organ weight and egg quality in freerange laying hens. $\mathrm{Br} 2018 ; 59(2)$ : 180-189. https://doi.org/10.1080/00071668.2017.1403566 
Isabel BASY, Santos Y. Effects of dietary organic acids and essential oils on growth performance and carcass characteristics of broiler chickens. J Appl Poult Res 2009; 18(3): 472-476. https://doi.org/10.3382/japr.2008-00096

Jahromi MF, Altaher YW, Shokryazdan P, Ebrahimi R, Ebrahimi M, Idrus Z, Liang JB. Dietary supplementation of a mixture of Lactobacillus strains enhances performance of broilerchickens raised underheatstress conditions. Int J Biometeorol 2016; 60(7): 1099-1110. https://doi.org/10.1007/s00484-015-1103-X

Jamroz D, Wiliczkiewicz A, Wertelecki T, Orda J, Skorupińska J. Use of active substances of plant origin in chicken diets based on maize and locally grown cereals. $\mathrm{Br} 2005$; 46(4): 485-493. https://doi.org/10.1080/00071660500191056

Jeong JS, Kim IH. Effect of fermented medicinal plants(Gynuraprocumbens, Rehmanniaglutinosa, Scutellariabaicalensis) as alternativeperformance enhancers in broilers. J Poult Sci2015; 0140061. https://doi.org/10.2141/jpsa.0140061

Klaver FA, Van der Meer R. The assumed assimilation of cholesterol by lactobacilli and Bifidobacterium bifidum is due to their bile salt-deconjugating activity. Appl Environ Microbiol 1993; 59(4): 1120-1124. https://doi.org/0099-2240/93/041120-05\$02.00/0

Kumar V, Cortan RS, Robbins SL. Robbins Basic Pathology. $7^{\text {th }}$ edition. 2003; Sunders, USA, Pp. 9-11.

LeeKW,Everts H, KapperstHJ, YeomKH, Beynen AC. Dietary carvacrol lowers body weight gain but improves feed conversion in female broiler chickens. J Appl Poult Res 2003; 12(4): 394-399. https://doi.org/10.1093/japr/12.4.394

Mahanta JD, Borgohain B, Sarma M, Sapcota D, Hussain J. Effect of dietary supplementation of herbal growth promoter on performance of commercial broiler chicken. Indian J Anim Res 2017; 51(6): 1097-1100. https://doi.org/10.18805/ijar.11420
Moorthy M, Ravi S, Ravikumar M, Viswanathan K, Edwin SC. Ginger, pepper and curry leaf powder as feed additives in broiler diet. Int J Poult Sci 2009; 8(8): 779-782. https://doi.org/10.3923/ijps.2009.779.782

Movahhedkhah S, Rasouli B, Seidavi A, Mazzei D, Laudadio V, Tufarelli V. Summer savory (Satureja hortensis L.) extract as natural feed additive in broilers: Effects on growth, plasma constituents, immune response, and ileal microflora. Animals 2019; 9(3): 87. https://doi.org/10.3390/ani9030087

Nacimento RA, Moro ME, Ferrari VB, Sanfelice LV, Pelissari PH, Sartore YG, Araújo LF. Oleoresins from chili pepper and turmeric could substitute for salinomycin in broilers. RCCP 2020; 33(3): 195-201. https://doi.org/10.17533/udea.rccp.v33n3a03

Nasiri S, Nobakht A, Safamehr A. The effects of different levels of nettle Urtica dioica L.(Urticaceae) medicinal plant in starter and grower feeds on performance, carcass traits, blood biochemical and immunity parameters of broilers. Iran J Appl Anim Sci 2011; 1(3): 177-181.

Nasiroleslami M, Torki M. Including essential oils of fennel (Foeniculum vulgare) and ginger (Zingiber officinale) to diet and evaluating performance of laying hens, white blood cell count and egg quality characteristics. Adv Environ Biol 2010; 341-346.

Nobakht A, Feazi B, Safamher AR. The effect of differentlevels of Tanacetumbalasmita, medicinal plant powder and extract on performance, carcass traits and blood parameters of Broiler Chicks. Iran J Appl Anim Sci 2015; 5(3): 665-671.

Ocak N, Erener G, Burak AkF, Sungu M, Altop A, Ozmen A. Performance of broilers fed diets supplemented with dry peppermint (Mentha piperita L.) or thyme (Thymus vulgaris L.) leaves as growth promoter source. Czech J Anim Sci 2008; 53(4): 169. https://doi.org/10.17221/373-CJAS 
Okoro VMO, Nwokeocha ACC, Ijezie CO, Mbajiorgu CA, Mbajiorgu EF. Effect of varying dietary supplemental inclusion levels of onion and garlic on semen quality characteristics of Hubbard white breeder broiler cocks aged 35-41 weeks old. Indian J Anim Res 2016; 50(6): 922-929. https://doi.org/10.18805/ijar.9378

Poorghasemi M, Chamani M, Mirhosseini SZ, Sadeghi AA, Seidavi A. Effect of probiotic and different sources of fat on performance, carcass characteristics, intestinal morphology and ghrelin gene expression on broiler chickens. Fak Derg 2018; 24(2): 169-178. https://doi.org/10.9775/kvfd.2017.18433

Poorghasemi M, Seidavi AR, Mohammadi M. Effect of inclusion of lemon balm (Melissa officinalis) extract into drinking water on ileum microflora of broilers. Int J Pharma Bio Sci 2014; 3(8): 1920-1925.

Poorghasemi M, Seidavi A, Qotbi A AA, Chambers JR, Laudadio V, Tufarelli V. Effect of dietary fat source on humoral immunity response of broiler chickens. Eur Poult Sci 2015; 79. https://10.1399/eps.2015.92

Rostami L, Taherpour K, Akbari Gharaei M, Ghasemi HA, Jamali J. Effects of different levels of Thymus vulgaris extract in comparison with antibiotics, Vitamin $\mathrm{C}$ and Vitamin $\mathrm{E}$ on performance, blood biochemistry and antibody response in broiler chickens under heat stress condition. J Vet Res 2020; 75(1): 26-37. https://doi.org/10.22059/jvr.2019.253178.2769

Ruiz-Feria CA. Concurrent supplementation of arginine, vitamin $\mathrm{E}$, and vitamin $\mathrm{C}$ improve cardiopulmonary performance in broilers chickens. Poult 2009; 88(3): 526-535. https://doi.org/10.3382/ps.2008-00401

Safa SEG, AL-Beitawi NA. The effect of feeding of crushed thyme (Thymus valgaris) on growth, blood constituents, gastrointestinal tract and carcass characteristics of broiler chickens. J Poult Sci 2009; 4(2): 100-104. https://doi.org/10.2141/jpsa.46.100
SAS. Statistical Analysis System. SAS user's guide. Version 9.4. Cary, NC, USA: SAS Institute Inc., 2019.

Sayyah M, Kamalinezhad M, Roustaeian A, Bahrami HR. Antiepileptic potential and composition of the fruit essential oil of Ferula gummosa boiss. Ferula gummosa. Iran Biomed 2001; 5: 15-16.

Soltan MA, Shewita RS, El-Katcha MI. Effect of dietary anise seeds supplementation on growth performance, immune response, carcass traits and some blood parameters of broiler chickens. Int. J Poult Sci 2008; 7(11): 1078-1088. https://doi.org/10.3923/ijps.2008.1078.1088

Souri H, Khatibjoo A, Taherpoor K, Hassan Abadi A, Fattahnia F, Askari M. Effect of Thymus vulgaris and Satureja khuzestanica ethanolic extracts on broiler chickens' performance and immune response. Iran J Appl Anim Sci 2015; 5(2): 437-446.

Tiihonen K, Kettunen H, Bento MHL, Saarinen M, Lahtinen S, OuwehandAC, RautonenN. The effect of feeding essential oils on broiler performance and gut microbiota. Br 2010, 51(3), 381-392. https://doi.org/10.1080/00071668.2010.496446

Vase-Khavari K, Mortezavi SH, Rasouli B, Khusro A, Salem AZ, Seidavi A. The effect of three tropical medicinal plants and superzist probiotic on growth performance, carcass characteristics, blood constitutes, immune response, and gut microflora of broiler. Trop Anim Health Prod 2019; 51(1): 33-42. https://doi.org/10.1007/s11250-018-1656-x

Webster D, Taschereau P, Lee TD, Jurgens T. Immunostimulant properties of Heracleum maximum Bartr. J Ethnopharmacol 2006;106(3): 360-363. https://doi.org/10.1016/j. jep.2006.01.018

Rev Colomb Cienc Pecu 2022; 35(4, Oct-Dec):191-204 https://doi.org/10.17533/udea.rccp.v35n3a03 